\title{
EFFECT OF FLAXSEED POWDER ON GROWTH PERFORMANCE AND SOME BLOOD CONSTITUENTS OF KARADI RAM LAMBS
}

\author{
MUHAMMAD K. ARIF \\ Department of Animal Production, Faculty of Agricultural Sciences, University of Sulaimani
}

Received: 19 April 2016; Accepted: 2 June 2016

\begin{abstract}
The present study was conducted at the sheep farm, research station fields of the faculty of agricultural sciences, University of Sulaimani at Bakrajo. The goal of this study was to evaluate the effects of adding flaxseed on growth performance and some blood constituents of ram lambs. The experiment was conducted in the Autumn of 2014 and involved 12 ram lambs that were divided into 3 groups of 4 animals according to the different levels of flaxseed supplementation: a traditional diet with no flaxseed supplementation (control group), low level (T1) and high level (T2) of flaxseed. The obtained Results concluded that addition of flaxseed in lamb rations had no significant effect on the blood plasma of total cholesterol, LDL and VHDL. In addition the plasma concentration of GOT and GPT enzymes were also not significantly affected by flaxseed supplementation.
\end{abstract}

Key words: Flaxseed; Blood parameters; Karadi lambs.

\section{INTRODUCTION}

Historically, flaxseed has been used in animal feeding for several thousand years in Europe, Asia and Africa, and more recently in Canada and United States. Oil pressed from flaxseed also has been basic cooking oil in China and other countries for centuries (Steven's farm, 2013). Flaxseed, or Linseed (Linumusitatissimmum), popularly known as Alsi, Jawas, Aksebija in Indian languages, is a blue flowering rabi crop and a member of family Linaceae. Annual production of flax was 3.06 million tons and Canada is the world's largest producer (about 38\% of total production) (Anonymous, 2000). Globally, Flaxseed is grown as either oil crop or a fiber crop with fiber linen derived from the stem of fiber varieties and oil from the seed of linseed varieties (Diederichsen et al., 2003; Vaisey-Genser et al., 2003). The plant is native to west Asia and the Mediterranean. As the source of linen fiber flax has been cultivated since at least $5000 \mathrm{BC}$, today it is mainly grown for its oil (Berugland, 2002; Oomah, 2001).

The potential benefits of using flaxseed as a feed necessitate a greater understanding of flaxseed in terms of nutrition in ruminants. Flaxseed on average contains $26 \%$ protein on a moisture-free basis, whereas solvent-extracted flaxseed meal consists of $44 \%$ CP on a moisture-free basis (Bhatty 1995).

Corresponding author: Dr. MUHAMMAD K. ARIF

E-mail address: hamakamal2004@yahoo.com

Present address: Department of Animal production, Faculty of Agricultural Sciences, University of Sulaimani
Linseed can be effectively used in feedlot ration, several research have demonstrated the use of up to $20 \%$ flaxseed in the diet without negatively affecting performance (Newkirk, 2008). Flaxseed benefits beside its nutritional value alone, however flax is a highly palatable feed ingredient and contains high levels of nutrients. It reduced incidence of bovine respiratory disease (Drouillard et al., 2004). Flaxseed is a richest land-based source of omega -3 which is considered as highly beneficial to human health and reduce the risk of cardiovascular diseases, mental disorders and arthritis (Eggie, 2010). Feeding beef cattle diets high in n-3 fatty acids is warranted for livestock producers interested in enhancing the human healthfulness of meat products (Weill et al., 2002) or increases (Drouillard et al., 2004) dietary intake, and an overall improvement in ADG is observed with inclusions of 5 to $8 \%$ flaxseed in the diet.

So this work was done to investigate the effects of flaxseeds inclusion at different levels in Karadi ram lambs rations on blood constituents and lipid profile.

\section{MATERIALS AND METHODS}

\section{Animals, Experimental Design, and Diets:}

To allow the animals to adapt the diets. They were fed the diet for 3 weeks before the experiment. The body weight was recorded at the beginning of the experiment and at the end of each week during the experiment. 
Each ram lamb was housed in a separate pen $(1 \mathrm{x} 1.5$ $\mathrm{m})$ during the experimental period. The concentrate mixture consist of wheat, barley, yellow corn, soybean meal and salt and mineral mixture. While barley straw was available ad libitum as a roughage (Table 1).

Table 1: Ingredients \%of the concentrate mixture.

\begin{tabular}{cccc}
\hline Item & Control & Low level (T1) & High level (T2) \\
\hline Wheat & 30 & 30 & 30 \\
\hline Barley & 41 & 37 & 33 \\
\hline Corn & 15 & 15 & 15 \\
\hline Soybean meal & 12 & 12 & 12 \\
\hline Flaxseed & 0 & 4 & 1 \\
\hline Mineral & 1 & 1 & 1 \\
\hline Salt & 1 & 1 & 8 \\
\hline
\end{tabular}

\section{Sampling, Measurements, and Analyses:}

Blood samples were obtained from each ram lamb every two weeks during the experimental period (2 months). The samples were collected before the morning feeding from the jugular veins by vein. The plasma was separated immediately after sampling by centrifugation at $3,000 \mathrm{rpm}$ for $15 \mathrm{~min}$. Plasma samples were analyzed for lipid profile, GOT, GPT, and ALP.

\section{Statistical Analyses:}

Descriptive data are reported as means \pm standard error, and the results were analyzed statistically by a multiple comparison one-way analysis of variance, with the level of significance set at $\mathrm{p}<0.05$. Statistical analysis system - XLstat. (2010) program was used for data analysis. The Complete Randomized Design (CRD) was used to study the effect of the three levels of Flaxseed (0, 4 and $8 \%$ of basal diet). Duncan (1955) multiple range test was used to determine the significant differences between means.

\section{RESULTS}

Live body weight (LBW) of lambs (kg):

LBW of ram lambs in the current study throughout the experimentis presented in Table (2). Final weights of the lambs assigned to the second treatment were heaver $(33.6 \pm 1.11 \mathrm{Kg})$ than lambs of the first treatment $(31.9 \pm 1.32 \mathrm{Kg})$ and the lambs of the control group $(32.4 \pm 1.19 \mathrm{Kg})$. Similarly, lambs assigned to the second treatment achieved the better performance in dry matter intake and daily weight gain.

Table 2: Effect of Flaxseed Powder on Live body weight (LBW) of lambs (Mean \pm SE) of Karadi Ram lambs.

\begin{tabular}{cccccc}
\hline & \multicolumn{5}{c}{ Body Weight $\mathbf{~ K g}$} \\
\cline { 2 - 6 } Items & \multicolumn{5}{c}{ Periods (8 weeks) } \\
\cline { 2 - 6 } & Initial & $\mathbf{2}$ & $\mathbf{4}$ & $\mathbf{6}$ & $\mathbf{8}$ \\
\hline $\mathbf{C}$ & $20.4 \pm 0.54$ & $21.9 \pm 0.71$ & $24.07 \pm 0.93$ & $27.1 \pm 1.2$ & $32.4 \pm 1.19$ \\
\hline T1 & $19.87 \pm 0.43$ & $21.1 \pm 0.80$ & $23.3 \pm 0.78$ & $26.08 \pm 0.87$ & $31.9 \pm 1.32$ \\
\hline T2 & $20.79 \pm 0.63$ & $22.09 \pm 1.10$ & $24.5 \pm 0.95$ & $27.5 \pm 1.3$ & $33.6 \pm 1.11$ \\
\hline
\end{tabular}

\section{Blood parameters:}

Serum Biochemical Characteristics:

\section{Alkaline phosphatase (ALP), Alanin aminotransferase (ALT or GPT) and Aspartate aminotranferase (AST or GOT):}

Table (3) indicates no significant differences $(\mathrm{P}<0.05)$ was noticed in the alkaline phosphatase concentration between control and treated groups.
Table (3) also shown no significant difference was noticed in the concentration of GPT enzyme between lambs of all the groups.

No significant difference was noticed in the concentration of GOT enzyme between lambs of the first and second treatment groups. However, there was a lower value between lambs of the first and second treatment as compared with lambs in control group (Table 3 ). 
Table 3: Effect of Flaxseed Powder on GOT, GPT and ALP of Karadi Ram lambs.

\begin{tabular}{|c|c|c|c|c|c|c|c|c|c|c|c|c|}
\hline \multirow{3}{*}{ Items } & \multicolumn{12}{|c|}{ Periods (8 weeks) } \\
\hline & \multicolumn{3}{|c|}{2} & \multicolumn{3}{|c|}{4} & \multicolumn{3}{|c|}{6} & \multicolumn{3}{|c|}{8} \\
\hline & $\mathbf{C}$ & T1 & $\mathbf{T} 2$ & $\mathbf{C}$ & T1 & $\mathbf{T} 2$ & $\mathbf{C}$ & T1 & $\mathbf{T} 2$ & C & T1 & $\mathbf{T} 2$ \\
\hline \multirow{2}{*}{ GOT } & $27 \pm$ & $17.15 \pm$ & $21.95 \pm$ & $33 \pm$ & $27 \pm$ & $23.32 \pm$ & $32 \pm$ & $27 \pm$ & $26.16 \pm$ & $36 \pm$ & $33.35 \pm$ & $29.15 \pm$ \\
\hline & 2.03 & 2.85 & 3.65 & 2.44 & 1.11 & 2.32 & 3.82 & 0.82 & 2.2 & 5 & 0.3 & 4.1 \\
\hline \multirow{2}{*}{ GPT } & $5.5 \pm$ & $3.5 \pm$ & $3.5 \pm$ & $6.72 \pm$ & $5.2 \pm$ & $3.8 \pm$ & $10.11 \pm$ & $7.11 \pm$ & $4.21 \pm$ & $12.7 \pm$ & $8.65 \pm$ & $4.5 \pm$ \\
\hline & 1.5 & 0.5 & 0.2 & 0.3 & 0.2 & 0.31 & $0.2 \mathrm{~A}$ & 0.3 & 0.36 & 2.6 & 0.35 & 0.5 \\
\hline \multirow{2}{*}{$\mathbf{A L P}$} & $189 \pm$ & $204 \pm$ & $233 \pm$ & $220 \pm$ & $330 \pm$ & $340 \pm$ & $333 \pm$ & $460 \pm$ & $401 \pm$ & $368 \pm$ & $554 \pm$ & $493 \pm$ \\
\hline & 19 & 16 & 29 & 20 & 44 & 38 & 19 & 21 & 23 & 18 & 11 & 10 \\
\hline
\end{tabular}

\section{Lipid profiles:}

The analysis of lipid profile revealed that the flaxseed had no influence on TC and TG. On the other hand diminished the LDL concentration and elevated HDL concentration.

Table 4: Effect of Flaxseed Powder on Lipid profiles (Mean \pm SE) of Karadi Ram lambs.

\begin{tabular}{|c|c|c|c|c|c|c|c|c|c|c|c|c|}
\hline \multirow{3}{*}{ Items } & \multicolumn{12}{|c|}{ Periods (8 weeks) } \\
\hline & \multicolumn{3}{|c|}{2} & \multicolumn{3}{|c|}{4} & \multicolumn{3}{|c|}{6} & \multicolumn{3}{|c|}{8} \\
\hline & $\mathbf{C}$ & $\mathbf{T 1}$ & $\mathbf{T 2}$ & C & $\mathbf{T 1}$ & $\mathbf{T} 2$ & $\mathbf{C}$ & T1 & $\mathbf{T} 2$ & $\mathbf{C}$ & T1 & $\mathbf{T} 2$ \\
\hline T.G & $\begin{array}{c}0.125 \pm \\
0.015\end{array}$ & $\begin{array}{c}0.085 \pm \\
0.005\end{array}$ & $\begin{array}{c}0.15 \pm \\
0.2\end{array}$ & $\begin{array}{c}0.120 \pm \\
0.02\end{array}$ & $\begin{array}{c}0.10 \pm \\
0.01\end{array}$ & $\begin{array}{c}0.12 \pm \\
0.1\end{array}$ & $\begin{array}{c}0.110 \pm \\
0.01\end{array}$ & $\begin{array}{c}0.09 \pm \\
0.01\end{array}$ & $\begin{array}{c}0.11 \pm \\
0.09\end{array}$ & $\begin{array}{c}0.105 \pm \\
0.005\end{array}$ & $\begin{array}{c}0.11 \pm \\
0.02\end{array}$ & $\begin{array}{c}0.12 \pm \\
0.01\end{array}$ \\
\hline T.C & $\begin{array}{c}0.67 \pm \\
0.2\end{array}$ & $\begin{array}{c}0.37 \pm \\
0.01\end{array}$ & $\begin{array}{c}0.62 \pm \\
0.1\end{array}$ & $\begin{array}{c}0.81 \pm \\
0.17\end{array}$ & $\begin{array}{c}0.64 \pm \\
0.04\end{array}$ & $\begin{array}{c}0.81 \pm \\
0.1\end{array}$ & $\begin{array}{c}1.06 \pm \\
0.2\end{array}$ & $\begin{array}{c}0.98 \pm \\
0.09\end{array}$ & $\begin{array}{c}0.92 \pm \\
0.11\end{array}$ & $\begin{array}{c}1.24 \pm \\
0.24\end{array}$ & $\begin{array}{c}1.34 \pm \\
0.1\end{array}$ & $\begin{array}{c}1.06 \pm \\
0.12\end{array}$ \\
\hline LDL & $\begin{array}{c}0.12 \pm \\
0.05\end{array}$ & $\begin{array}{c}0.03 \pm \\
0.01\end{array}$ & $\begin{array}{c}0.09 \pm \\
0.05\end{array}$ & $\begin{array}{c}0.20 \pm \\
0.03\end{array}$ & $\begin{array}{c}0.20 \pm \\
0.1\end{array}$ & $\begin{array}{c}0.12 \pm \\
0.05\end{array}$ & $\begin{array}{c}0.31 \pm \\
0.08\end{array}$ & $\begin{array}{c}0.36 \pm \\
0.11\end{array}$ & $\begin{array}{c}0.18 \pm \\
0.01\end{array}$ & $\begin{array}{c}0.35 \pm \\
0.08\end{array}$ & $\begin{array}{c}0.48 \pm \\
0.21\end{array}$ & $\begin{array}{l}0.21 \pm \\
0.005\end{array}$ \\
\hline HDL & $\begin{array}{c}0.46 \pm \\
0.18\end{array}$ & $\begin{array}{c}0.30 \pm \\
0.01\end{array}$ & $\begin{array}{c}0.49 \pm \\
0.05\end{array}$ & $\begin{array}{c}0.40 \pm \\
0.1\end{array}$ & $\begin{array}{c}0.35 \pm \\
0.13\end{array}$ & $\begin{array}{c}0.55 \pm \\
0.1\end{array}$ & $\begin{array}{c}0.34 \pm \\
0.11\end{array}$ & $\begin{array}{c}0.44 \pm \\
0.1\end{array}$ & $\begin{array}{c}0.63 \pm \\
0.09\end{array}$ & $\begin{array}{c}0.28 \pm \\
0.11\end{array}$ & $\begin{array}{c}0.53 \pm \\
0.18\end{array}$ & $\begin{array}{c}0.67 \pm \\
0.11\end{array}$ \\
\hline VHDL & $\begin{array}{c}0.12 \pm \\
0.09\end{array}$ & $\begin{array}{l}0.01 \pm \\
0.001\end{array}$ & $\begin{array}{c}0.08 \pm \\
0.05\end{array}$ & $\begin{array}{c}0.07 \pm \\
0.01\end{array}$ & $\begin{array}{l}0.01 \pm \\
0.002\end{array}$ & $\begin{array}{c}0.05 \pm \\
0.01\end{array}$ & $\begin{array}{c}0.04 \pm \\
0.01\end{array}$ & $\begin{array}{c}0.021 \pm \\
0.002\end{array}$ & $\begin{array}{c}0.032 \pm \\
0.005\end{array}$ & $\begin{array}{c}0.021 \pm \\
0.001\end{array}$ & $\begin{array}{c}0.032 \pm \\
0.004\end{array}$ & $\begin{array}{c}0.024 \pm \\
0.002\end{array}$ \\
\hline
\end{tabular}

\section{DISCUSSION}

Flax components also have antioxidant properties and, hence, may reduce the activity of cell-damaging free radicals (Prasad, 2001). Significant to the animal feed area is the protein component in flaxseed that is very similar to that of soybean protein. Flaxseed also contains a number of important essential minerals and minor amounts of water- and fat-soluble vitamins. Furthermore, Slominski et al. (2006) examined the potential to increase nutrient utilization with a combination of fibre-degrading enzymes. However Matthews et al. (2000) fed rations with 0, 5 or $10 \%$. For finishing cattle and reported that an increases in performance and efficiency, as well as an increase in marbling of meat (Maddock et al., 2006). He also found that use whole flaxseed had no impact on animal performance. Bethke et al. (1928) reported that using $10 \%$ linseed meal in beef calf diets had no effecton animal performance. Weber (1934) studied the relative value of linseed meal and reported enhanced growth and feed conversion in cattle.

The ALP enzyme test is important because of its role in showing the conditions of liver and bile duct. This enzyme enters the padded cells and the level of ALP in blood serum increases when damages happened in the bile duct (Coles, 1974). 
These results were in agreement with those obtained by Hamed et al. (2013). However, there was a higher value in the control group compared with treated groups. Also when GPT rises in the blood serum it is an indication of tissue damages which happened during dystocia and reproductive diseases (Bugalia, 1996).

As previously reported by Petit et al. (2001), feeding flaxseed decreased blood-cholesterol concentration compared with no feeding flaxseed. The lower cholesterol levels in the diets could be likely due to increased polyunsaturated fatty acids compared to the control diet, but this is speculation. Our findings corroborate with previous reports that demonstrated modulation of lipid metabolism with supplementation with flaxseed. This is in agreement with Abdullah et al. (2013). While, Ray (2011) noted that flaxseed helps to lower overall cholesterol levels, especially low density lipoprotein (LDL). In contrast, Bruso (2011) noted that total cholesterol was not reduced with flax supplementation. These results were in agreement with those obtained by Abdullah et al. (2013).

\section{CONCLUSION}

Under the conditions of this study, the obtained results mentioned that incorporation of flaxseed in ram lamb ration shad no significant effect on blood parameters such as (cholesterol, triglycerides, alkaline phosphatease, GOT and GPT) of lambs. Flaxseed is emerging as one of the nutritive and functional ingredient in food products. Scientific findings are growing in support of flaxseed consumption. More studies are needed to resolve the conflicting reports regarding the health benefits.

\section{REFERENCES}

Abdullah, M.N.; Abo, N.Y.; Almallah, O.D. and Abdullah, G.I. (2013): Effect of Using Flaxseed in The Rations Components in Reproductive Performance of Awassi Ewes. (1), (3), (4) Nenivah. Res. Dept. / State Board of Agric. Res./ Ministry of Agric. / Iraq.

Anonymous (2000): Oil World Statistics Update. Oil World 31: 9-10.

Bethke, R.M.; Bohstedt, G.; Sassaman, H.L.; Kennard, D.C. and Edginton, B.H. (1928): Journal of Anima Science 1:21-25.

Bhatty, R.S. (1995): Nutrient composition of whole flaxseed and flaxseed meal. Pages 22-42 in Cunane, S. and Thompson, L. U. eds. Flaxseed in Human Nutrition. AOCS press. Champaign, IL, USA.

Berglund, D.R. (2002): Flax: New uses and demands. In Janick, J. and Whipkey, A. (Eds.).Trends in new crops and new uses, p. 358-360. Alexandria: ASHS Press.
Bruso, J. (2011): Does flaxseed help to lower cholesterol?

Coles, E.H. (1974): Veternary clinical pathology. 2nd ed. W. B. Saunders Co. Philadelphia, London, Toronto.

Drouillard, J.S.; Seyfert, M.A.; Good, E.J.; Loe, E.R.; Depenbusch, B. and Daubert, R. (2004): Flaxseed for finishing beef cattle: Effects on animal performance, carcass quality, and meat composition. Pages 108-117 in Proc. 60th Flax Inst., Fargo, ND. Flax Inst., Dept. Plant Sci., Fargo, ND.

Diederichsen, A. and Richards, K. (2003): Cultivated flax and the genus Linnum L.: taxonomy and gerplasm conservation. In Muir, A.D. and Westcott, N.D. (Eds). Flax, The genus Linum, p. 22-54. London: Taylor and Francis. http://www.livestrong.com/article/359327.

Duncan, D.B. (1955): Multiple ranges and multiple (F). Bio-metrics 1:42.

Eggie, Kael (2010): Development of an extruded flax-based feed ingredient. Diss. McGill University.

Hamed A.A. Omer; Sawsan M. Ahmed; AbdElMaged A. Abedol and Azza M.M. Badr (2013): Utilization of Flaxseeds (Linumusitatissimum L.) in Rabbit Rations. 2. Influence of Flaxseeds Levels Supplementations on Blood Constituents, Carcass Characteristics and Fatty Acids Profile. Life Science Journal 2013; 10 (4).

Matthews, K.R.; Homer, D.B.; Thies, F. and Calder, P.C. (2000): Effect of whole linseed (Linumusitatissiumum) in the diet of finishing pigs on growth performance and on the quality and fatty acid composition of various tissues. Brit. J. Nutrition 83:637-643.

Maddock, T.D.; Bauer, M.L.; Koch, K.B.; Anderson, V.L.; Maddock, R.J.; Barceló-Coblijn, G.; Murphy, E.J. and Lardy, G.P. (2006): Effect of processing flax in 116 beef feed lot diets on performance, carcass characteristics, and trained sensory panel ratings. J. Anim. Sci. 84: 1544-1551.

Oomah, B.D. (2001): Flaxseed as a functional food source. Journal of the Science of Food and Agricultural. 81 (9): 889-894.

Petit, H.V.; Dewhurst, R.J.; Proulx, J.G.; Khalid, M.; Haresign, W. and Twagiramungu, H. (2001): Milk production, milk composition, and reproductive function of dairy cows fed different fats. Can. J. Anim. Sci. 81: 263_271.

Prasad, K. (2001): Secoisolariciresinoldiglucoside from flaxseed delays the development of type 2 diabetes in Zucker rat. J. Lab. Clin. Med.138:32-39.

Ray, L. (2011): Benefits of flaxseed in the diet, reducing cholesterol. http://www.livestrong. com/article/83994benefits.

Slominski, B.A.; Meng, X.; Campbell, L.D. and Guenter, W. and Jones, O. (2006): The use of 
enzyme technology for improved energy utilization from full-fat oilseeds. Part II: Flaxseed. Poultry Science 85: 1031-1037.

Steven's farm (2013): What is flaxseed? http://www.stevensfarm.com/pages/faqs.

Vaisey-Genser, M. and Morris, D.H. (2003): Introduction: history of the cultivation and uses of flaxseed. In Muir, A. D. and Westcott, N. D. (Eds). Flax: The genus Linum. p. 1-2. London: Taylor and Francis.
Weill, P.; Schmitt, B.; Chesneau, G.; Daniel, N.; Safraou, F. and Legrand, P. (2002): Effects of introducing linseed in livestock diet on blood fatty acid composition of consumers of animal products. Ann. Nutr. Metab. 46:182191.

Weber, A.D. (1934): The relative value of cottonseed meal, linseed meal, and corn gluten meal in fattening cattle rations. J. Anim. Sci. 1:70-72.

XLstat., 7.5.2, (2010). www.xlstat.com

\section{تاثير مسحوق بدور الكتان على اداء النمو وبعض مكونات الام في ذكور حملان الكرادي \\ محمد كمال عارف}

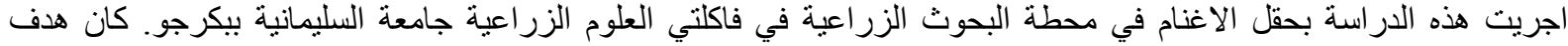

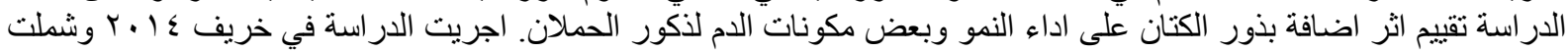

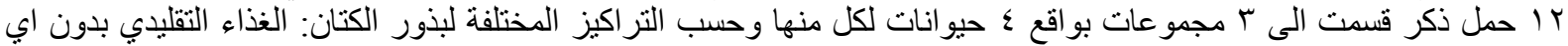

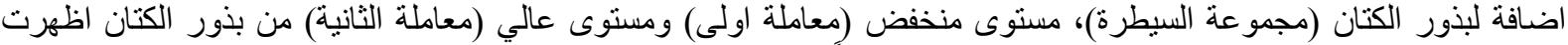
النتائج ان اضافة بذور الكتان في علائق الحملان لم يؤثر معنوياً على اداء النمو وبعض مكونات الدم التي تم قياسها.
} 